\title{
Molluscum Contagiosum Virus Infection
}

National Cancer Institute

\section{Source}

National Cancer Institute. Molluscum Contagiosum Virus Infection. NCI Thesaurus. Code C155872.

An infection that is caused by molluscum contagiosum virus. 